Bert Droste-Franke - Boris P. Paal - Christian Rehtanz • Dirk Uwe Sauer • Jens-Peter Schneider • Miranda Schreurs • Thomas Ziesemer

\title{
Balancing \\ Renewable Electricity
}

Energy Storage,

Demand Side Management, and Network Extension from an Interdisciplinary Perspective

In collaboration with

Ruth Klüser and Theresa Noll

包 Springer 


\section{Contents}

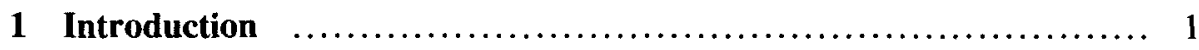

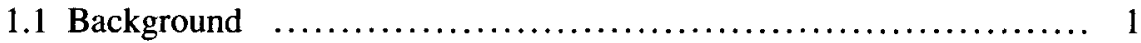

1.2 Renewable Energies in the European Energy Mix $\ldots \ldots \ldots \ldots \ldots \ldots . \ldots 3$

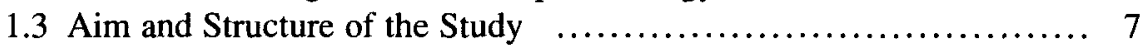

2 Future Perspectives of Electrical Energy Supply ................. 9

2.1 Aims for a Long-Term Viable Development

of a Renewable-Based Electricity System $\ldots \ldots \ldots \ldots \ldots \ldots \ldots . . . \ldots$

2.1.1 Efficient Allocation and Just Distribution $\ldots \ldots \ldots \ldots \ldots \ldots \ldots . . \ldots$

2.1.2 An Operative Action Rule .......................... 11

2.2 Indicators for the Evaluation of Balancing Strategies $\ldots \ldots \ldots \ldots \ldots 12$

2.2.1 Indicators for Environmental Effects ................... 13

2.2.2 Indicators for Resource Availability $\ldots \ldots \ldots \ldots \ldots \ldots \ldots . \ldots 14$

2.2.3 Indicators for the Design of the Energy Supply System ..... 16

2.3 Political Governance Towards a Renewable Energy Electricity

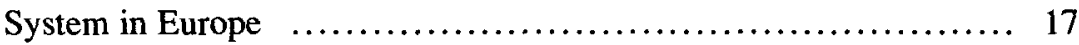

2.3.1 Historical Background, Current Status and Development of Europe's Energy System ......................... 17

2.3.1.1 Europe's Growing Energy Dependence $\ldots \ldots \ldots \ldots \ldots .17$

2.3.1.2 Climate Change Constraints $\ldots \ldots \ldots \ldots \ldots \ldots \ldots \ldots . .18$

2.3.1.3 Climate Change as a Driving Force Behind the Search for a Low-Carbon Electricity System $\ldots \ldots \ldots \ldots \ldots 18$

2.3.1.4 Growing Diversification of the Energy Supply ...... 18

2.3.1.5 Trends in Renewable Energy Production in Europe ... 19

2.3.2 Political Governance Activities for Organising

the Future Energy System $\ldots . \ldots \ldots \ldots \ldots \ldots \ldots \ldots \ldots \ldots . . \ldots 19$

2.3.2.1 Regional Cooperation in Developing Renewables ..... 19

2.3.2.2 National Actions Within the EU on Climate Change

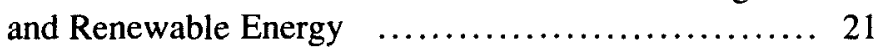

2.3.2.3 European Policies for a Low-Carbon Energy Market .. 24

2.3.2.4 The European Energy Council of 2011 ........... 28

2.3.2.5 Moving Towards Higher Emission Reduction

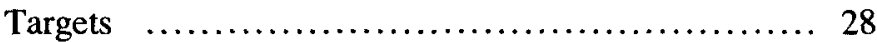


2.3.2.6 Roadmap for a Low-Carbon Economy in 2050 ...... 28

2.3.2.7 Supporting Infrastructure Development for Renewable Energy $\ldots \ldots \ldots \ldots \ldots \ldots \ldots \ldots \ldots . . . \ldots 29$

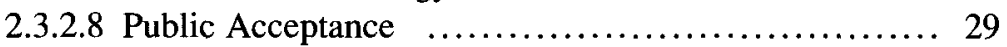

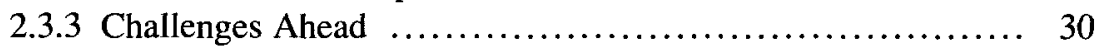

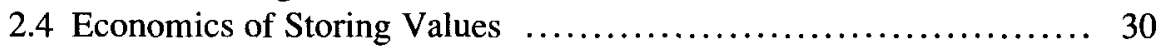

2.4.1 Energy Economic Background $\ldots \ldots \ldots \ldots \ldots \ldots \ldots \ldots \ldots ., 30$

2.4.2 Theory of Storing Values $\ldots \ldots \ldots \ldots \ldots \ldots \ldots \ldots \ldots \ldots \ldots, 32$

2.4.2.1 Storing Values Without Technologies .............. 32

2.4.2.2 Storing Values Using Technologies ............... 33

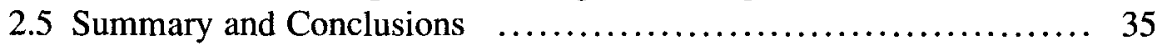

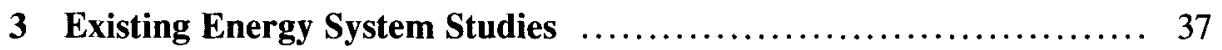

3.1 Applicability of Existing Future Energy Scenarios

as Framework Conditions for the Analysis of Strategies $\ldots \ldots \ldots \ldots 37$

3.1.1 Energy System Modelling: A Theoretical Perspective ....... 38

3.1.2 Basic Approaches in Energy System Analysis Followed in This Study and Data Requirements $\ldots \ldots \ldots \ldots \ldots \ldots \ldots . . . \ldots .41$

3.1.3 Comparison of Relevant Energy System Analyses According to Their General Characteristics ............... 44

3.2 The Derivation of Future Electricity Supply Parameters as Inputs for the Analysis of Balancing Strategies .............. 49

3.2.1 Assumptions in the Political Renewable Energy Sources (RES) Scenario: Intensified Funding ............. 51

3.2.2 Assumptions According to the Lead Scenario 2009 ......... 51

3.2.3 Effects on the Conventional Power Station Park ........... 52

3.2.3.1 Renewable Energy Sources ..................... 52

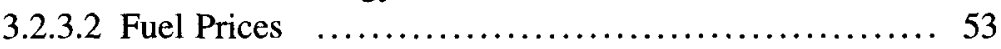

3.2.3.3 Resulting Power Station Parks ................ 55

3.2.4 Evaluation of Development Paths ..................... 56

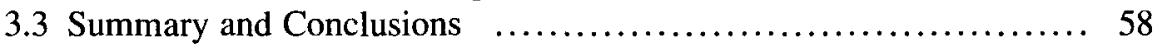

4 Demand for Balancing Electrical Energy and Power $\ldots \ldots \ldots \ldots \ldots 61$

4.1 Assessing the Balancing Demand and Storage Employment

Based on Scenarios for Germany $\ldots \ldots \ldots \ldots \ldots \ldots \ldots \ldots \ldots \ldots . \ldots 1$

4.1.1 Assessing the Demand of Balancing Electrical

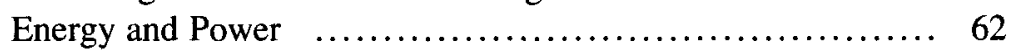

4.1.1.1 Effect on the Residual Load and the Available

Power Station Power ........................ 62

4.1.1.2 Characteristics of Possible Wind Calms Lasting

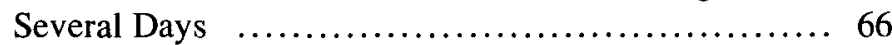

4.1.1.3 Dimensioning the Necessary Storage Capacity ...... 66

4.1.2 Estimation of the Storage Employment $\ldots \ldots \ldots \ldots \ldots \ldots \ldots .70$ 
4.2 Assessing the Storage Demand Based on an Optimised Pan-European Low-Carbon Electrical Energy Supply Strategy ..... 73

4.2.1 General Aspects and Boundary Conditions $\ldots \ldots \ldots \ldots \ldots . . . \ldots 73$

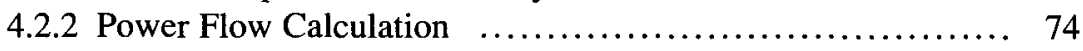

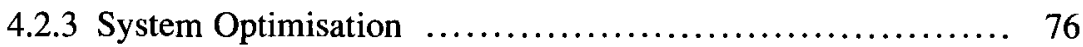

4.2.4 Cost Data and Other Assumptions $\ldots \ldots \ldots \ldots \ldots \ldots \ldots \ldots . \ldots 77$

4.2.5 First Model Results ....................................... 79

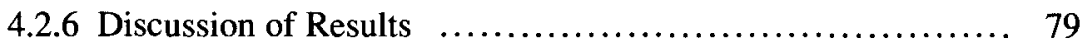

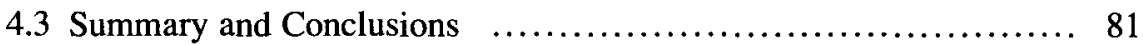

5 Technologies for Balancing Electrical Energy and Power .......... 83

5.1 Classification of Energy Storage Systems and Systems

Offering Positive and Negative Control Power .................. 83

5.2 Technical Description of "Electricity to Electricity"

Energy Storage Technologies for a Balanced Electrical

Energy and Power Supply $\ldots \ldots \ldots \ldots \ldots \ldots \ldots \ldots \ldots \ldots \ldots . \ldots \ldots$

5.2.1 "Mechanical" Storage Systems for Electric Power ......... 86

5.2.1.1 Compressed Air Energy Storage (CAES) $\ldots \ldots \ldots \ldots \ldots 86$

5.2.1.2 Pumped Hydropower Plants $\ldots \ldots \ldots \ldots \ldots \ldots \ldots \ldots . . \ldots 0$

5.2.1.3 Hydro Storage Systems $\ldots \ldots \ldots \ldots \ldots \ldots \ldots \ldots \ldots . \ldots 1$

5.2.1.4 Flywheels ................................. 91

5.2.2 "Electrical" Storage Systems for Electric Power $\ldots \ldots \ldots \ldots .92$

5.2.2.1 Electrochemical Double-Layer Capacitors

("Supercaps") $\ldots \ldots \ldots \ldots \ldots \ldots \ldots \ldots \ldots \ldots \ldots \ldots . \ldots 2$

5.2.2.2 Superconducting Coils $\ldots \ldots \ldots \ldots \ldots \ldots \ldots \ldots \ldots \ldots . \ldots 3$

5.2.3 "Chemical" Storage Systems for Electric Power ........... 93

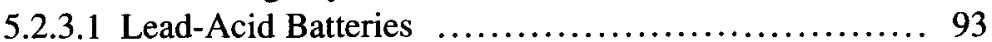

5.2.3.2 High Temperature Sodium-Based Batteries ......... 94

5.2.3.3 Lithium-Ion Batteries ....................... 95

5.2.3.4 Nickel Cadmium (NiCd) and Nickel-Metal-Hydride (NiMH) Batteries ........................... 95

5.2.3.5 Redox-Flow Batteries $\ldots \ldots \ldots \ldots \ldots \ldots \ldots \ldots \ldots \ldots . \ldots 6$

5.2.3.6 Hydrogen Storage Systems ................... 97

5.3 Technical Description and Potential of "Electricity to Anything" Energy Storage Technologies for a Balanced Electrical Energy

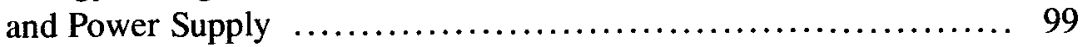

5.3 .1 DSM Industrial Sector $\ldots \ldots \ldots \ldots \ldots \ldots \ldots \ldots \ldots \ldots \ldots \ldots, 100$

5.3.2 Balance Provision by Electrical Mobility $\ldots \ldots \ldots \ldots \ldots \ldots .100$

5.3.3 DSM Household Sector $\ldots \ldots \ldots \ldots \ldots \ldots \ldots \ldots \ldots \ldots \ldots . \ldots 1$

5.3.3.1 Technical Potential of DSM in the Household

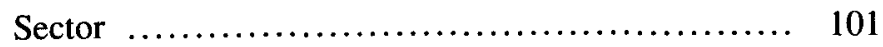

5.3.3.2 Expected Economic Benefits from DSM in the Household Sector ............................ 105

5.3.4 Shutdown of Renewable Power Generation ............. 108

5.3.5 Generation of Chemical Fuels such as Hydrogen,

Methane or Methanol from Electricity 
5.4 Technical Description of "Anything to Electricity"

Energy Storage Technologies for a Balanced Electrical

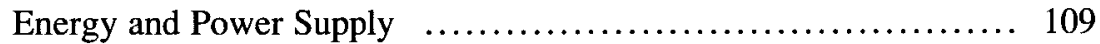

5.4.1 CHP Plants with Thermal Storage ...................... 109

5.4.2 Conventional Power Plants Using Fossil, Nuclear,

Hydro or Biofuels

5.5 Conclusions on Options for Demand Response

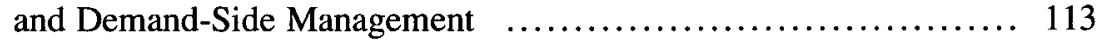

5.6 Life Cycle Cost Analysis of Storage Technologies $\ldots \ldots \ldots \ldots \ldots . . . \ldots 114$

5.7 Assessment of Future Viability of the Technologies'

Environmental Issues, Resource Use and System Characteristics $\ldots 119$

5.7.1 Methodology and Data Applied for Quantitative

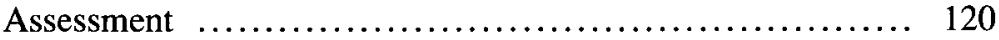

5.7.2 Environmental Impacts $\ldots \ldots \ldots \ldots \ldots \ldots \ldots \ldots \ldots \ldots \ldots . \ldots \ldots$

5.7.2.1 Assessment Methodology and Assumptions ....... 120

5.7.2.2 Environmental External Costs of Balancing

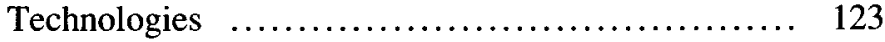

5.7.2.3 Environmental Impacts of Balancing Technologies

Differentiated into Categories ................ 126

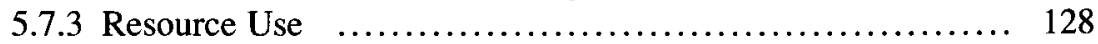

5.7.3.1 Types and Amounts of Resources Required ....... 128

5.7.3.2 Current Availability of Relevant Mineral

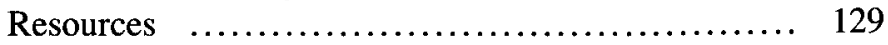

5.7.3.3 Resource Potentials for the Production of Balancing Technologies $\ldots \ldots \ldots \ldots \ldots \ldots \ldots \ldots . \ldots \ldots 131$

5.7.4 System Characteristics Relevant for Society .............. 134

5.7.4.1 Supply Reliability .......................... 135

5.7.4.2 Risk Avoidance $\ldots \ldots \ldots \ldots \ldots \ldots \ldots \ldots \ldots \ldots \ldots . \ldots \ldots$

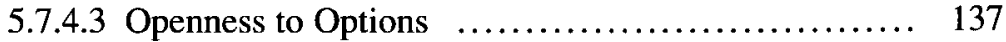

5.7.5 Conclusions on the Future Viability of Various

Approaches to Energy Storage $\ldots \ldots \ldots \ldots \ldots \ldots \ldots \ldots \ldots . \ldots \ldots . \ldots \ldots$

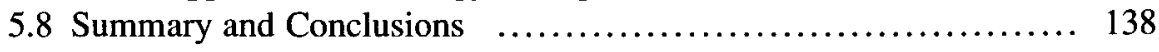

6 Technology of Electricity Networks and Economical Impacts $\ldots \ldots .143$

6.1 Assessment of Technical Barriers Considering the

Total System Including Network Requirements $\ldots \ldots \ldots \ldots \ldots \ldots . . \ldots 143$

6.1.1 Interaction of Load Control with the

Distribution Network ............................. 143

6.1.2 Transmission Network Expansion $\ldots \ldots \ldots \ldots \ldots \ldots \ldots \ldots \ldots . . \ldots 149$

6.2 Economical Impacts of Balancing Activities at the Daily

and Seasonal Scales

6.2.1 Distribution Network Requirements

for Avoiding Restrictions

6.2.2 Effects of the Transmission Network

Expansion Measures 
6.2.3 Conclusions on Economical Impacts

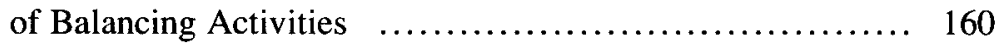

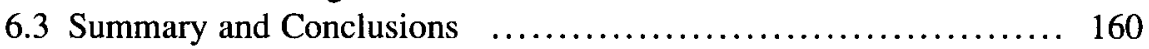

7 Economic Analysis and Policy $\ldots \ldots \ldots \ldots \ldots \ldots \ldots \ldots \ldots \ldots \ldots \ldots . \ldots \ldots$

7.1 Problems in a Market Economy without Economic Policy:

Weather-Based Supply and Culturally Caused

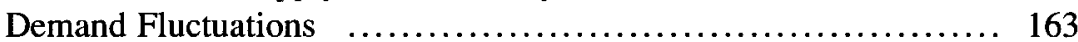

7.1.1 The Insurance Function of the Market $\ldots \ldots \ldots \ldots \ldots \ldots \ldots . .63$

7.1.2 Fluctuations and Smoothing of Electricity Demand: Energy

Saving Reduces the Demand for Storage Facilities $\ldots \ldots \ldots \ldots 164$

7.1.3 Fluctuations and Smoothing of Supply $\ldots \ldots \ldots \ldots \ldots \ldots \ldots . \ldots 166$

7.1.4 Coordination of Supply and Demand $\ldots \ldots \ldots \ldots \ldots \ldots \ldots . \ldots 6$

7.1.5 Aspects of Long-Run Developments ................... 167

7.1.6 Towards a Theory of Location for Storage Facilities ....... 168

7.2 Analysis of Economic Framework Conditions ................. 169

7.2.1 Introduction: The Theory of Economic Policy ............ 169

7.2.2 The Theory of Economic Policy in the Area

of Environmental and Technology Problems ............ 170

7.2.2.1 Tradable $\mathrm{CO}_{2}$ Permits, Taxes and Other

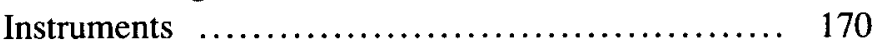

7.2.2.2 Research and Technical Progress: Trusting Markets Only Versus Support for Complementary Technologies? .............................. 171

7.2.2.3 Beyond Pigovian Corrections ................ 172

7.2.2.4 Policies for Imported Resources

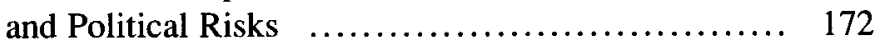

7.2.3 The Current Practice of Government Support ............. 172

7.2.4 Stylised Views on Economic Policy: First Best, Second Best, History and Transition $\ldots \ldots \ldots \ldots \ldots \ldots \ldots \ldots . \ldots \ldots$

7.2.4.1 First Best ................................... 173

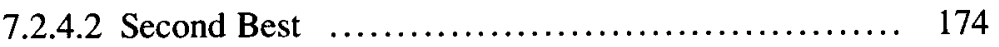

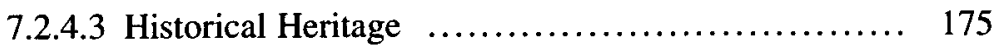

7.2.4.4 Transition to Science Based Views ............. 175

7.2.5 Economic Policy Recommendations ................. 176

7.3 Summary and Conclusions $\ldots \ldots \ldots \ldots \ldots \ldots \ldots \ldots \ldots \ldots \ldots \ldots \ldots \ldots \ldots$

8 Legal Analysis of Balancing Strategies $\ldots \ldots \ldots \ldots \ldots \ldots \ldots \ldots \ldots \ldots$

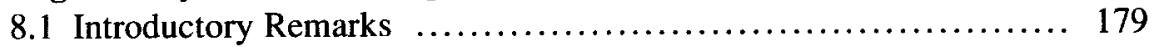

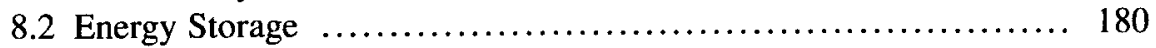

8.2.1 Centralised Storage Systems $\ldots \ldots \ldots \ldots \ldots \ldots \ldots \ldots \ldots \ldots$

8.2.1.1 Planning and Licensing $\ldots \ldots \ldots \ldots \ldots \ldots \ldots \ldots \ldots, 180$

8.2.1.2 Regulatory Incentives $\ldots \ldots \ldots \ldots \ldots \ldots \ldots \ldots \ldots \ldots, 181$

8.2 .1 .3 Access $\ldots \ldots \ldots \ldots \ldots \ldots \ldots \ldots \ldots \ldots \ldots \ldots \ldots \ldots, 181$

8.2.1.4 Unbundling $\ldots \ldots \ldots \ldots \ldots \ldots \ldots \ldots \ldots \ldots \ldots \ldots \ldots, 184$ 
8.2.2 Decentralised Storage Systems, Especially E-mobility $\ldots \ldots .185$

8.2.2.1 Legal Relationships $\ldots \ldots \ldots \ldots \ldots \ldots \ldots \ldots \ldots \ldots \ldots, 185$

8.2.2.2 Contractual Relationships Within Networks ....... 187

8.2.2.3 Questions Concerning Data Protection ............ 189

8.3 Balancing Strategies in Distribution Grids $\ldots \ldots \ldots \ldots \ldots \ldots \ldots . \ldots 190$

8.3.1 Smart Meter ................................... 190

8.3.1.1 Topics Regarding Data Protection $\ldots \ldots \ldots \ldots \ldots \ldots \ldots . . \ldots 1$

8.3.1.2 Contractual Relationships in Networks ............ 195

8.3.2 Smart Grid/Demand-Side Management ................ 195

8.3.2.1 Data Protection ............................ 196

8.3.2.2 Contractual Relationships in Networks ........... 196

8.4 Transmission Network Expansion $\ldots \ldots \ldots \ldots \ldots \ldots \ldots \ldots \ldots \ldots \ldots . \ldots . \ldots 196$

8.4.1 The Status Quo for Planning and Licensing

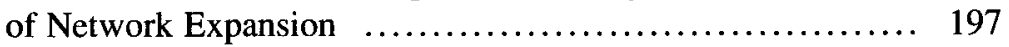

8.4.2 The Status Quo of Investment Regulation as Part of Economic Energy Regulation $\ldots \ldots \ldots \ldots \ldots \ldots \ldots \ldots . \ldots \ldots$

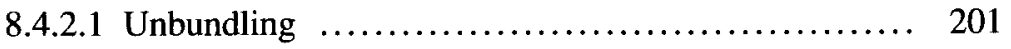

8.4.2.2 Network Investment Duties for TSOs ........... 201

8.4.2.3 Investment Planning Duties of TSOs as an Instrument of Reflexive Steering $\ldots . \ldots \ldots \ldots \ldots \ldots .203$

8.4.2.4 Investment Incentives and Securing Investments as an Aspect of Price Regulation ................ 205

8.4.3 Concepts for a Reform of Planning, Licensing and Regulating of Network Expansion .................. 207

8.4.3.1 National Concepts ........................... 207

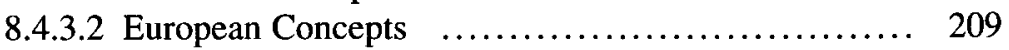

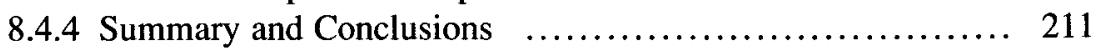

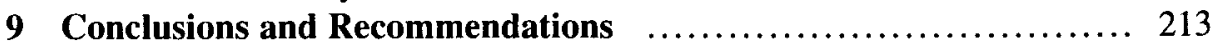

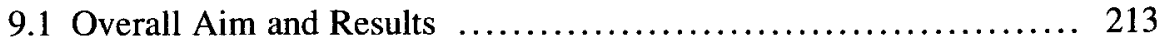

9.2 Challenges and Recommendations $\ldots \ldots \ldots \ldots \ldots \ldots \ldots \ldots \ldots . \ldots . \ldots . \ldots . \ldots 214$

9.2.1 Development of Technical Infrastructure ................ 215

9.2.2 Framework Conditions and Organisational Aspects ........ 217

9.2.2.1 Market Conditions for Balancing Technologies ..... 217

9.2.2.2 Specific Support for the Application of Balancing Technologies $\ldots . . . \ldots \ldots \ldots \ldots \ldots . \ldots .220$

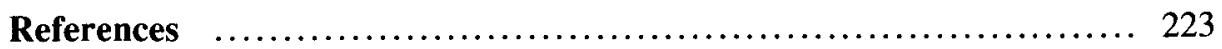

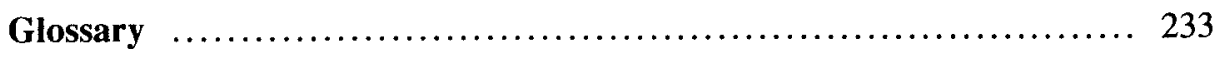

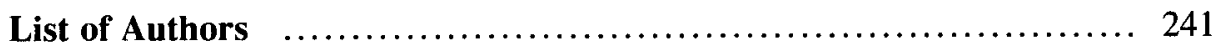

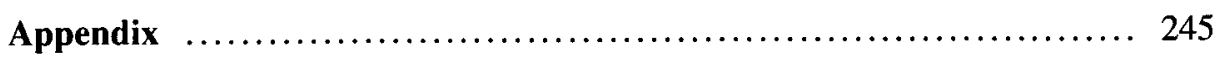

Further volumes of the series Ethics of Science and Technology Assessment (Wissenschaftsethik und Technikfolgenbeurteilung) $\ldots \ldots \ldots \ldots \ldots .251$ 